\title{
Pelatihan Penyusunan Ransum Ruminansia dengan Metode Sederhana di Kelompok Tani Ternak Jaya Makmur Desa Sidamulih Kecamatan Sidamulih Kabupaten Pangandaran
}

\author{
A Simple Ruminant Feed Formulation Training at Jaya Makmur \\ Farmers Group, Sidamulih Pangandaran
}

\author{
Endah Yuniarti ${ }^{1, a}$, Raden Febrianto Christi ${ }^{2}$, Diky Ramdani ${ }^{2}$ \\ ${ }^{1}$ Program Studi Peternakan k. Pangandaran, Universitas Padjadjaran \\ ${ }^{2}$ Departemen Produksi Ternak, Fakultas Peternakan, Universitas Padjadjaran \\ aemail: yuniarti.en@gmail.com
}

\begin{abstract}
Abstrak
Pakan merupakan salah satu faktor utama dalam produksi peternakan karena pakan menghabiskan $60-70 \%$ biaya produksi. Pemberian ransum yang baik dan pemilihan bahan pakan yang tepat menjadi salah satu kemampuan yang harus dikuasai oleh peternak. Kemampuan tersebut diharapkan mampu menjadikan biaya produksi peternakan menjadi lebih efisien. Berdasarkan hal tersebut, maka diperlukan adanya sebuah program yang dapat menjadi sarana transfer informasi terkait penyusunan ransum kepada peternak. Kelompok Tani Ternak Jaya Makmur Desa Sidamulih Kecamatan Sidamulih Kabupaten Pangandaran merupakan kelompok peternak ruminansia yang mengalami kendala dalam teknis beternak terutama masalah pemberian pakan. Pelatihan penyusunan ransum dilaksanakan dengan harapan mampu membantu peternak menyelesaikan permasalahannya. Pelatihan ini dilaksanakan secara tatap muka dengan penerapan protocol kesehatan yang ketat. Pelatihah ini berjalan dengan lancar karena antusiasme peserta yang tinggi. Selain itu, setelah mengikuti pelatihan ini peserta menjadi paham perbedaan antara bahan pakan dan ransum, golongan bahan pakan, kebutuhan bahan kering ternak berdasarkan bobot badan, kandungan bahan kering pakan, serta cara menyusun ransum ternak yang baik.
\end{abstract}

Kata Kunci: pakan, bahan pakan, penyusunan ransum, bahan kering, Pangandaran

\begin{abstract}
Animal Feeding is one of the main factors in livestock production because it consumes $60-70 \%$ of production costs. Providing the best ration and selecting the right feed ingredients are among the capabilities that must be mastered by farmers. These capabilities are expected to be able to make a more efficient livestock production costs. Based on these, it was necessary to have a program than can be a tool of transferring the information that related to the skills of formulating the ration to the farmers. Jaya Makmur Livestock Farmers Group at Sidamulih Pangandaran is a ruminant farmers group that has technical difficulties in farming, especially the problem of animal feeding. Feed Formulation training was carried out with the hope of being able to help farmers solve their problem. This training was offline with strict application of health protocols. This training was carried out well because of the high enthusiasm of the participants. Furthermore, after participating in this training, the participants understood the difference between feed ingredients and rations, types of feed ingredients, dry matter needs for animal base on body weight, dry matter content of feed, and how to formulate good ruminant rations.
\end{abstract}

Keywords: feed, feed ingredient, feed formulation, dry matter, Pangandaran 


\section{Pendahuluan}

Kabupaten Pangandaran merupakan wilayah yang berada di bagian selatan Jawa Barat dan wilayah administrasi baru hasil pemekaran dari Kabupaten Ciamis. Kabupaten Pangandaran terbentuk sejak tahun 2012 berdasarkan UU No. 21/2012 yang terdiri dari 10 kecamatan, yaitu Kecamatan Parigi, Kecamatan Cijulang, Kecamatan Cimerak, Kecamatan Cigugur, Kecamatan Langkaplancar, Kecamatan Mangunjaya, Kecamatan Padaherang, Kecamatan Kalipucang, Kecamatan Pangandaran, dan Kecamatan Sidamulih. Wilayah Kabupaten Pangandaran memiliki banyak potensi alam seperti pertanian, peternakan, perikanan, dan pariwisata. Rencana Tata Ruang Wilayah Kabupaten Pangandaran Tahun 2018-2038 menyebutkan bahwa kawasan peruntukkan budidaya ternak ruminansia besar dan kecil tersebar di seluruh kecamatan di Kabupaten Pangandaran, termasuk Kecamatan Sidamulih.

BPS (2018) mencatat bahwa pada tahun 2015 Kecamatan Sidamulih memiliki jumlah populasi ternak ruminansia besar yang terdiri dari sapi (1.508 ekor), kerbau (33 ekor) dan kuda (21 ekor). Selain itu, populasi ruminansia kecil di wilayah ini pada tahun 2015 tercatat sebanyak 7.007 ekor domba dan 646 ekor kambing. Banyaknya jumlah populasi ruminansia di Kabupaten Sidamulih merupakan potensi yang harus terus dikembangkan serta didukung oleh seluruh stakeholder terkait. Perkembangan peternakan di suatu daerah diharapkan mampu mendukung swasembada pangan dan meningkatkan perekonomian masyarakat.

Peternakan ruminansia yang ada di masyarakat sebagian besar masih berbasis peternakan rakyat, sehingga keterbatasan sarana dan prasarana menjadi salah satu kendala yang sering ditemukan. Selain itu, peternak yang memiliki tingkat pendidikan formal yang rendah juga merupakan kendala terutama dalam hal kemampuan mengadopsi teknologi dan inovasi pelaksanaan teknis manajemen peternakan. Maka dari itu, di Desa Sidamulih terbentuklah Kelompok Tani Ternak Jaya Makmur yang menjadi wadah bekerjasama bagi para peternak. Anggota kelompok ini terdiri dari peternak yang membudidayakan kambing dan domba pedaging, kambing perah, dan sapi.

Sumber daya manusia yang terhimpun dalam Kelompok Tani Ternak Jaya Makmur merupakan suatu faktor yang sangat utama dalam menentukan tingkat perkembangan kelembagaan atau peternakan. Amam et al. (2019) mengatakan bahwa SDM berfungsi sebagai penggerak, pemikir, dan perencana untuk mencapai tujuan organisasi atau kelembagaan peternak. Ada beberapa upaya yang dapat dilakukan untuk mengoptimalkan peran dan fungsi peternak melalui kelompok tani ternak (Amam et al., 2019), yaitu meningkatkan kapasitas penyuluh lapang, menggunakan pendekatan pastisipasif yang berorientasi pada kebutuhan petani dan memperkuat kelembagaan petani.

Salah satu permasalahan teknis pemeliharaan ternak yang dihadapi oleh anggota Kelompok Tani Ternak Jaya Makmur adalah pemberian pakan. Peternak belum mendapatkan informasi terkait dengan pemberian pakan yang baik dan benar, serta cara menyusun ransumnya. Peternak selama ini hanya mengandalkan pengamatan sederhana terhadap tingkah laku ternak. Peternak mendefinisikan suara berisik dari ternak merupakan pertanda lapar dan saat ternak diam (tidak bersuara gaduh), maka itu pertanda sudah kenyang. Hal ini rentan menimbulkan masalah berikutnya, yaitu tidak efisiennya pemberian pakan dikarenakan pakan yang diberikan tidak berdasarkan pada kebutuhan nutrien ternaknya. Dengan demikian, tujuan dari Pengabdian Kepada Masyarakat ini adalah untuk memberikan pelatihan penyusunan ransum ternak ruminansia dengan menggunakan metode sederhana bagi anggota Kelompok Tani Ternak Jaya Makmur di Desa Sidamulih, Kecamatan Sidamulih, Kabupaten Pangandaran.

\section{Metode Pelaksanaan}

Pengabdian Kepada Masyarakat (PKM) ini dilaksanakan pada bulan September 2020 dan bertempat di peternakan kambing perah "Raudhotul 
Ghanam" Desa Sidamulih, Kecamatan Sidamulih, Kabupaten Pangandaran. PKM ini dilaksanakan dalam bentuk pelatihan tatap muka dengan penerapan prinsip protokol kesehatan yang ketat. Pelatihan ini dilaksanakan dengan beberapa tahapan yang dilakukan, yaitu tahapan persiapan, penyuluhan dan demonstasi, serta evaluasi.

Tahapan pertama yang dilakukan adalah identifikasi masalah, studi literatur untuk mendukung pemecahan masalah, persiapan perizinan, tempat dan jadwal pelaksanaan. Tahapan berikutnya adalah penyuluhan dan demonstrasi. Pada tahapan penyuluhan, kegiatan yang dilaksanakan terdiri dari: pembagian kuisioner (Pre-test) dengan tujuan mengukur sejauh mana informasi atau pengetahuan yang sudah didapatkan oleh peserta, ceramah, praktek penyusunan ransum, serta dilanjutkan dengan diskusi. Tahapan akhir dari pelatihan ini adalah evaluasi peserta menggunakan tanya jawab secara langsung dan kuisioner (post-test). Evaluasi ini dilakukan dengan tujuan mengetahui sejauh mana peserta mendapatkan informasi terbaru dibandingkan sebelum mengikuti pelatihan.

\section{Hasil dan Pembahasan}

Pelatihan penyusunan ransum yang dilaksanakan melalui Pengabdian Kepada Masyarakat (PKM) ini merupakan salah satu Tri Dharma Perguruan Tinggi. Adanya program PKM ini diharapkan mampu menjadi salah satu solusi dalam mentransfer ilmu pengetahuan terhadap masyarakat. Dengan ilmu pengetahuan ini, masyarakat diharapkan mampu memecahkan permasalahan yang dihadapi serta meningkatkan kesejahteraan hidup.

Program PKM ini diawali dengan tahapan identifikasi masalah melalui wawancara langsung kepada ketua Kelompok Tani Ternak Jaya Makmur Desa Sidamulih Kecamatan Sidamulih Kabupaten Pangandaran. Berdasarkan hasil wawancara didapat beberapa masalah yang dihadapi oleh peternak anggota kelompok ini. Salah satu masalah yang dihadapi adalah terkait pemberian pakan. Peternak belum mendapatkan informasi yang valid tentang cara pemberian pakan yang baik, termasuk jumlah pakan yang harus diberikan dan jenis pakan yang baik bagi ternak. Berdasarkan hasil wawancara tersebut, selanjutnya proses penyusunan agenda penyuluhan bagi peternak dilakukan guna mendapatkan sasaran dan luaran yang tepat.

Penyusunan ransum yang baik dan benar merupakan salah satu faktor yang harus diperhatikan dalam sebuah peternakan. Hal ini disebabkan pakan merupakan salah satu komponen utama yang menunjang produksi peternakan dengan persentase biaya produksi $60-70 \%$ berasal dari pakan (Mayasari et al., 2018; Setiyatwan et al., 2018; Baba et al., 2011). Selama ini, peternak di Kelompok Tani Ternak Jaya Makmur Desa Sidamulih Kecamatan Sidamulih Pangandaran hanya mengandalkan rumput lapang yang diarit sendiri oleh peternak untuk pakan ternak mereka. Selain itu, mereka juga mengandalkan limbah pertanian, seperti daun ubi, daun dan kulit kacang tanah, sedangkan untuk pemberian konsentrat tidak terlalu diperhatikan oleh peternak, adapun pemberiannya pernah dilakukan namun peternak tidak mengetahui kandungan nutrien dan bahan pakan yang dipakai dalam konsentrat komersil tersebut. Hal ini menyebabkan peternak masih berpikir bahwa memberikan konsentrat pada ternak tanpa mengetahui kandungannya lebih banyak mengeluarkan biaya produksi dibandingkan dengan mengarit rumput meskipun jarak yang harus ditempuh tidak selalu dekat.

Pelatihan penyusunan ransum ruminansia dilaksanakan dengan terlebih dahulu menyampaikan informasi kepada peternak tentang perbedaan bahan pakan dan ransum, serta jenis dan golongan bahan pakan yang digunakan dalam menyusun ransum. Berdasarkan kuisioner yang dibagikan pada peternak dan tanya jawab secara langsung, hampir seluruh peserta yang hadir belum mengetahui perbedaan antara pakan dan ransum. Selain itu, peserta juga masih terlihat bingung saat menyebutkan golongan bahan pakan dan contohnya.

Keberhasilan pemeliharaan ternak ditentukan oleh banyak faktor, salah satunya adalah ketersediaan ransum yang memenuhi 
kebutuhan nutrient ternak dan ekonomis (Agustono et al., 2017; Dewanti et al., 2013) - Pemberian materi pada pelatihan penyusunan ransum ini berdasarkan tabel kebutuhan nutrisi ternak (Kearl, 1982) dan tabel komposisi bahan makanan untuk ternak di Indonesia (Hartadi et al., 1980). Peserta diberi pemahaman bahwa pakan dan ransum adalah dua istilah yang berbeda. Pakan merupakan bahan yang digunakan dalam menyusun ransum ternak, terdiri dari sumber energy, sumber protein, sumber vitamin dan mineral, serta suplemen dan bahan additive (jika diperlukan). Pakan yang berkualitas adalah pakan yang mampu mencukupi kebutuhan nutrient ternak, dapat dicerna, dan memiliki tingkat kecernaan yang tinggi (Maluyu, 2020). Ransum merupakan pakan yang dibutuhkan ternak selama 24 jam sesuai dengan kebutuhan nutrisinya. Selanjutnya, peserta diajak untuk belajar secara aktif bagaimana menyusun ransum yang benar diawali dengan menentukan kebutuhan bahan kering berdasarkan bobot badan ternak. Kebutuhan bahan kering ini menjadi landasan kecukupan pemberian pakan dalam satu hari.

Tahapan berikutnya adalah menggolongkan jenis pakan yang biasa peternak gunakan ke dalam beberapa golongan seperti sumber energy dan protein. Kedua golongan ini lebih utama untuk disampaikan karena kedua komponen tersebut adalah kebutuhan yang paling besar di dalam ransum ternak. Selain itu, keterbatasan waktu juga menjadi pertimbangan penyampainan materi. Berdasarkan hasil kuisioner yang dibagikan kepada peserta, maka didapatkan hasil berupa beberapa bahan pakan yang biasa digunakan oleh peternak, yaitu rumput, ampas tahu, jerami, silase, dan daun singkong. Setelah setiap bahan pakan digolongkan, peserta dibimbing untuk menentukan kadar bahan kering setiap bahan pakan dengan mengacu pada tabel komposisi pakan Hartadi et. al (1980). Konsumsi bahan kering merupakan faktor pembatas pemenuhan kebutuhan nutrein ternak yang diperlukan untuk hidup pokokm pertumbuhan, dan produksi (Nono et al., 2020). Bahan kering juga merupakan salah satu faktor kunci untuk menentukan efisiensi pakan yang dikonsumsi oleh ternak (Seymour et al., 2019). Dengan diketahuinya kebutuhan bahan kering ternak dan kandungan bahan kering pakan, maka peternak akan lebih mudah menghitung berapa bahan yang harus diberikan kepada ternak dalam satu hari.

Tahapan diskusi dengan peserta dilaksanakan setelah pemaparan materi dan simulasi penyusunan ransum selesai. Sesi diskusi ini berjalan dengan baik karena antusiasme dari peserta yang tinggi. Hal ini dibuktikan dengan banyaknya pertanyaan yang disampaikan oleh peserta seperti tentang tata cara menyimpan stok pakan yang baik, pembuatan dan pemberian silase, serta seputar kesehatan ternak yang berhubungan dengan pakan. Selain menyampaikan pertanyaan, peserta juga secara aktif menyampaikan pengalamanpengalaman yang mereka temukan selama pemeliharaan ternak.

Pelatihan penyusunan ransum ini diakhiri dengan sesi evaluasi, dimana peserta diminta untuk mengisi kuisioner guna mengukur sejauh mana pemahaman peserta sebelum dan sesudah mendapatkan pelatihan. Perubahan respon peserta sebelum dan sesudah mendapatkan pelatihan dijelaskan pada Gambar 1 dan Gambar 2. 


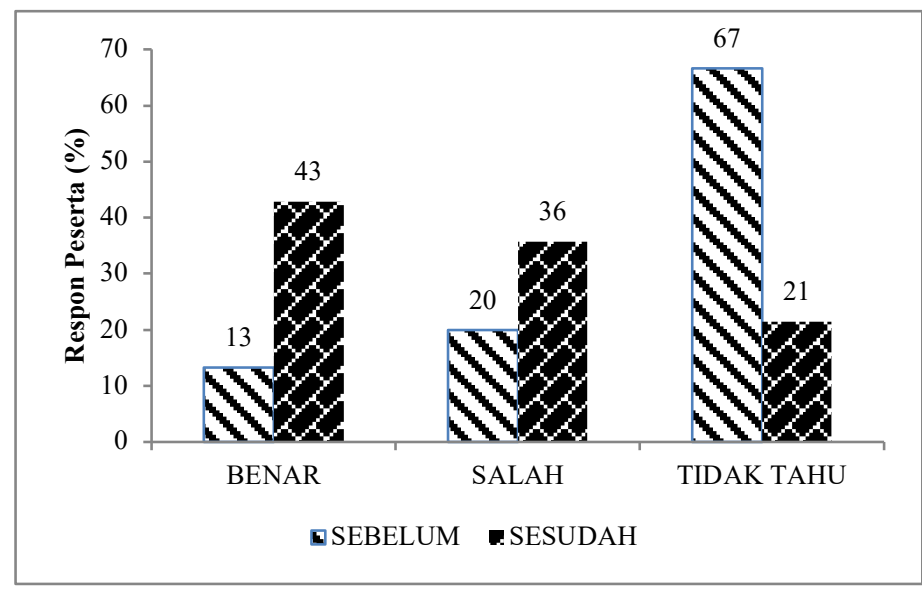

Gambar 1. Respon Peserta Tentang Pengertian Ransum Sebelum dan Sesudah Pelatihan

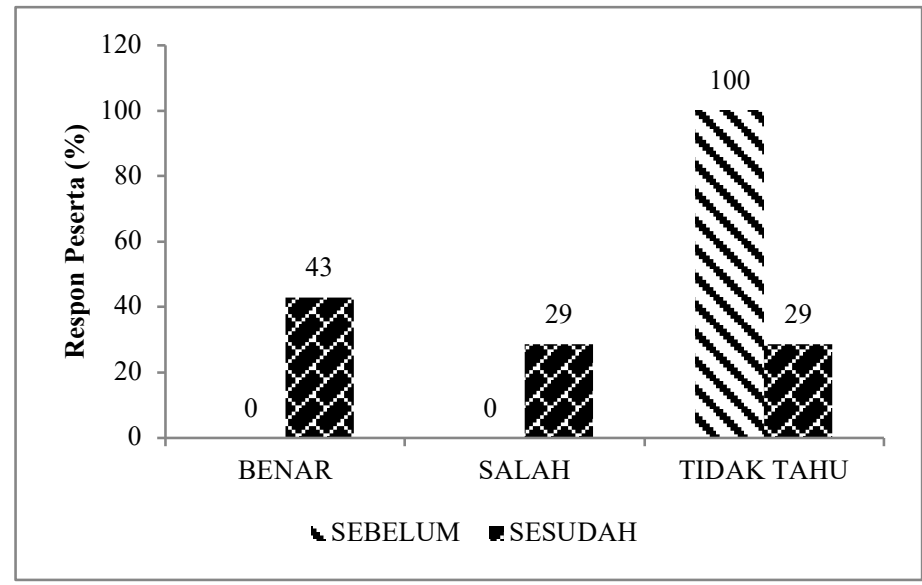

Gambar 2. Respon Peserta Tentang Formulasi Ransum Sebelum dan Sesudah Pelatihan

\begin{abstract}
Pemahaman peserta tentang pengertian bahan ransum mengalami peningkatan sebesar $30 \%$ berdasarkan jawaban yang benar setelah pendapatkan pelatihan dibandingkan dengan sebelum pelatihan dilaksanakan. Hal yang sama juga ditunjukkan pada Gambar 2, dimana pemahaman peserta tentang formulasi meningkat setelah mendapatkan pelatihan sebesar $43 \%$ dibandingkan dengan sebeleum pelatihan. Berdasarkan hasil evaluasi tersebut, sebagian peserta sudah mengerti dasar pemberian pakan ternak yang baik beserta jumlah yang harus diberikan. Selain itu, peserta juga menyampaikan harapannya tentang pelatihan dan penyuluhan yang kontinu, sehingga dalam penerapan ilmu pengetahuan yang sudah didapat, peternak pun bisa tetap dibimbing untuk mengevaluasinya.
\end{abstract}

\section{Kesimpulan}

Pelatihan penyusunan ransum ruminansia di Kelompok Tani Ternak Jaya Makmur Desa Sidamulih Kecamatan Sidamulih Kabupaten Pangandaran berjalan dengan baik karena antusiasme peserta yang tinggi. Selain itu, pelatihan ini menjadi salah satu media transfer informasi terhadap peternak terkait perbedaan bahan pakan dan ransum, golongan bahan pakan dan kandungan bahan keringnya, kebutuhan bahan kering ternak berdasarkan bobot badan, serta penyusunan ransum ternak yang baik. Manfaat lain yang dirasakan melalui pelatihan ini adalah adanya proses bertukar informasi antara pengalaman lapangan peternak dengan ilmu pengetahuan yang dipelajari di perguruan tinggi. 


\section{Ucapan Terimakasih}

Ucapan terimakasih disampaikan kepada ketua Kelompok Tani Ternak Jaya Makmur Desa Sidamulih Kecamatan Sidamulih Kabupaten Pangandaran yang telah memberikan kesempatan terlaksananya program Pengabdian Kepada Masyarakat. Selain itu, terimakasih juga diucapkan kepada Peternakan "Raudhotul Ghanam" Desa Sidamulih Kecamatan Sidamulih Kabupaten Pangandaran atas bantuan berupa sarana dan prasarana sehingga kegiatan ini berjalan dengan lancar.

\section{Daftar Pustaka}

Agustono, B., Ma'ruf, A., Lamid, M., \& Purnama, M. T. E. (2017). Identification of Agricultural and Plantation Byproducts as Inconventional Feed Nutrition in Banyuwangi. Jurnal Medik Veteriner, 1(1), 12-22. https://www.researchgate.net/publicatio $\mathrm{n} / 322095385$

Amam, A., Jadmiko, M. W., Harsita, P. A., \& Poerwoko, M. S. (2019). Model Pengembangan Usaha Ternak Sapi Perah Berdasarkan Faktor Aksesibilitas Sumber Daya. Jurnal Sain Peternakan Indonesia, 14(1), 61-69. https://doi.org/10.31186/jspi.id.14.1.6169

Baba, S., Muktiani, A., Ako, A., \& Dagong, M. I. A. (2011). Keragaman dan kebutuhan teknologi pakan peternak sapi perah di kabupaten enrekang. Media Peternakan, 34(2), 146-154. https://doi.org/10.5398/medpet.2011.34. 2.146

Dewanti, R., Irham, M., \& Sudiyono. (2013). Pengaruh penggunaan enceng gondok (. 37(1),

19-25. https://doi.org/https://doi.org/10.21059/ buletinpeternak.v37i1.1955

Mayasari, N., Salman, L. B., Setyowati, E. Y., \& Ismiraj, M. R. (2018). Pembuatan Ransum Komplit Dengan Pemanfaatan Indigofera Zollingeriana Dan Mineral Anorganik: Peningkatan Kesehatan Dan Produktivitas Sapi Perah Pada Kelompok Ternak Sapi Perah KSU Tandangsari, Kecamatan Tanjungsari,
Kabupaten Sumedang. 2(4). http://journal.unpad.ac.id/pkm/article/vi ew/19630/9635

Mayulu, H. (2020). HKI-Buku Karakteristik Pakan Ruminansia. Diakses pada 24 Januari 2020 melalui: https://repository.unmul.ac.id/bitstream/ handle/123456789/4976/19HAMDI\%20 MAYULU\%20KARAKTERISTIK\%20 PAKAN\%20RUMINANSIA.pdf?seque nce $=1$

Nono, M. M., Maranatha, G., Rosnah, U. S., \& Yunus, M. (2020). Konsumsi dan Kecernaan Bahan Kering dan Bahan Organik Sapi Bali Penggemukan yang Mendapat Suplemen Mengandung Bonggol Pisang Terfermentasi dengan Pakan Basal Pola Peternak di Tingkat on Farm (Intake and digestibility of dry and organik matter of on-farm. 2(2), 826-833.

http://publikasi.undana.ac.id/index.php/ JPLK/article/view/582

Seymour, D. J., Cánovas, A., Baes, C. F., Chud, T. C. S., Osborne, V. R., Cant, J. P., Brito, L. F., Gredler-Grandl, B., Finocchiaro, R., Veerkamp, R. F., de Haas, Y., \& Miglior, F. (2019). Invited review: Determination of large-scale individual dry matter intake phenotypes in dairy cattle. Journal of Dairy Science, 102(9), 7655-7663. https://doi.org/10.3168/jds.2019-16454

Setiyatwan, H., E. Harlia, and D. Rusmana. 2018. Budidaya dan Aplikasi Teknologi Pengolahan Duckweed (Lemna Sp.) Sebagai Pakan Konsentrat Serta Penggunaannya Untuk Ternak Itik di Desa Sidomulyo dan Desa Wonoharjo Kecamatan Pangandaran Kabupaten Pangandaran. J. Pengabdi. Kpd. Masy. 2:1-5. ISSN: 1410 - 5675 / E-ISSN: 2620-8431. Diakses dari: http://jurnal. unpad.ac.id/pkm/article/view/16536/803 8.

Tillman, A. D., Hartadi, H., Reksohadiprodjo, S., Prawirokusumo, S., \& Lebdosoekojo, S. (1998). Ilmu makanan ternak dasar. 